\title{
FACTORS IN GOLD DOSAGE AND TOXICITY IN RHEUMATOID ARTHRITIS
}

\author{
BY \\ J. S. LAWRENCE \\ From the Miners' Clinic, Walkden, and the Rheumatism Research Centre of the University of Manchester
}

(RECEIVED FOR PUBLICATION FEBRUARY 17, 1953)

Since the discovery of cortisone, the gold treatment of rheumatoid arthritis has been overshadowed by the dramatic action of this new remedy. As both cortisone and ACTH have been shown to be capable of maintaining their effect in a proportion of cases with appropriate maintenance dosage, and particularly as cortisone can be given by mouth, it would appear at first sight that there can no longer be a place for chrysotherapy in the treatment of this group of disorders. Though this may come to be the position in the future it certainly is not so at present, and until supplies of these newer agents are adequate to serve the needs of all rheumatoid sufferers, gold will continue to be used. It is essential, therefore, that it be used to the greatest advantage and any means by which toxicity can be reduced without impairment of therapeutic benefit must be carefully investigated.

The ability of gold to induce remissions in rheumatoid arthritis has been shown by controlled therapeutic trials (Ellman and Lawrence, 1938a, b; Ellman and others, 1940; Fraser, 1945; Kling and others, 1949), but the high relapse rates (Egelius and others, 1952) show that the effect at least with present therapeutic dosage is not curative, relapse being particularly frequent when low dosage has been used (Short and others, 1948; Browning and others, 1947). Owing to the very slow excretion rate of gold, however, relapses may not occur for some considerable time, and even after an observation period of 9 years patients treated with gold have been found to fare better than those receiving other methods of treatment (Kling and others, 1949). That the effect of gold is proportional to dosage has been shown in animals by Sabin and Warren (1940), and in man by Ellman and others (1940). Some workers have suggested that dosage of the order of $50 \mathrm{mg}$. weekly may be as effective as a larger dose (Freyberg and others, 1941 ; Comroe, 1945), but they have produced no statistical evidence in support of their claim. The indications from animal experiments are that the optimum total dosage is of the order of $100 \mathrm{mg}$. $/ \mathrm{kg}$. (6 g. $/ 60 \mathrm{~kg}$.) given over the shortest possible time.

It would appear, therefore, that successful gold treatment depends on administering a maximum dosage of gold whilst at the same time avoiding its more dangerous side-effects. Before discussing how this may best be achieved, it is necessary to consider certain pharmacological properties of gold.

Gold compounds injected intramuscularly are slowly absorbed from the site of injection, attaining, with normal therapeutic dosage, a maximum blood level of up to $2 \mathrm{mg}$. $/ 100 \mathrm{ml}$. of plasma by the 4 th weekly injection. After stopping treatment the blood level slowly falls; reaches half its final level by the 9th week, but still continues to show detectable amounts at the end of the 4th month. Gold can be detected in the urine up to 10 months after stopping treatment (Freyberg and others, 1941; Hartung and others, 1941), and has been discovered in the tissues after periods of up to 3 years. In the blood, gold is combined with the plasma proteins (Freyberg and others, 1944). This gold-protein complex is a chemical compound and does not release gold ions in solution (Libenson, 1945). As colloids and other substances of high molecular weight present in the plasma can pass out of the circulation only through damaged capillaries, they tend to become concentrated at a site of induced inflammation (Menkin, 1936). It follows that gold in its combination with protein will not readily pass into the tissues except at a focus of inflammation. In a patient with active rheumatoid arthritis the gold will thus pass largely into the inflamed synovial tissues, and the concentration in such tissue has, in fact, been found to be some 18 times as great as in, for example, the skin (Bertrand and others, 1948). Thus, so long as there is active exudation into the diseased tissues, the danger of toxic effects in the skin, mucous 
membrane, or haemopoietic tissue is likely to be reduced. As the disease process subsides, however, this shunting effect will diminish and the danger of gold deposition in healthy tissues will be liable to increase, which explains the tendency for toxic effects to be greater in those patients who derive the greatest benefit and greater in rheumatoid arthritis than in a resistant disease such as tuberculosis. It would also explain the inverse relationship between the erythrocyte sedimentation rate and gold toxicity noted by Ellman and others (1940), a relationship which is not absolute since toxic effects may arise when the erythrocyte sedimentation rate is still raised (Goldie, 1939; Price and Leichtentritt, 1943). The most serious and persistent manifestations nearly always arise when quiescence has been reached. In Goldie's series, for example, the erythrocyte sedimentation rate was below $10 \mathrm{~mm}$. during the 2 weeks before the onset in eight out of eleven examples of desquamating erythema. In my own experience, though stomatitis and drug rashes frequently arise in patients in whom the erythrocyte sedimentation rate is still high, they are invariably transient. The persistent forms of stomatitis and dermatitis which were at one time such a distressing feature of chrysotherapy do not occur till the disease is almost or wholly quiescent.

\section{Present Experiments}

On the basis of these impressions and in view of the importance of giving the maximum tolerated dose, it was decided to treat a series of patients on a new schedule. In this the maximum dose was given from the start and was based on a scale related to the extent and activity of the disease process as measured by the erythrocyte sedimentation rate or preferably to the actual plasma fibrinogen concentration of which the erythrocyte sedimentation rate is an indirect measure. A fractional viscosity method (Lawrence, 1949, 1950) may conveniently be used for estimating the plasma fibrinogen. The corresponding viscosity differences are therefore given in Table I, which also shows the dosage.

Dosage.-The erythrocyte sedimentation rate or plasma fibrinogen is taken at 4-weekly intervals and the subsequent dosage regulated according to the same scale. Thus a female patient with an erythrocyte sedimentation rate of $50 \mathrm{~mm}$. would start with a weekly dose of $200 \mathrm{mg}$., and this would be continued till the erythrocyte sedimen tation rate fell below $25 \mathrm{~mm}$. If, for example, it fell tQ. $20 \mathrm{~mm}$. the dose was reduced to $100 \mathrm{mg}$. weekly, if to under $15 \mathrm{~mm}$. the dose fell to $50 \mathrm{mg}$. weekly. If th erythrocyte sedimentation rate rose, the dosage was in? creased again in accordance with the scale. No fixed lime was placed on total dosage unless this was necessitate by the appearance of toxic symptoms, but treatment was discontinued when the erythrocyte sedimentation rats had remained within normal limits for 2 months. When plasma fibrinogen values were substituted for the erythrocyte sedimentation rate it was found possible to include in the higher dosage group many cases in whicht the erythrocyte sedimentation rate was proving a faf lacious guide to the activity of the disease process and to prolong treatment till recovery was more complete. the erythrocyte sedimentation rate alone was used, the danger of an increased value due to anaemia had to b borne in mind. In such cases estimation of the plasma. fibrinogen is essential.

Toxic Side-Effects. - Table II (opposite) shows the toxie symptoms in ninety patients. Thirty of these were treated on the old schedule and received two courses each of $2.5 \mathrm{~g}$. gold at a weekly dosage of $200 \mathrm{mg}$., followin $\Phi$ the customary initial dose of $10,20,50$, and $100 \mathrm{mg}$ at weekly intervals. These patients showed frequent toxieg effects, and in many the symptoms were severe, stomatitis and extensive dermatitis causing great distress persisting for many months. One patient in this group develope agranulocytosis and purpura and died (Ellman an Lawrence, 1935).

Thirty others received $100 \mathrm{mg}$. weekly up to a totap of $1.5 \mathrm{~g}$. for each of two courses. Toxic effects were less frequent, stomatitis being comparatively rare an dermatitis less frequent. Blood and liver disorders were not encountered in this group. Nevertheless, the stoma? titis and dermatitis of patients treated with such dosage may be severe and prolonged and fatal agranulocytosis not unknown.

In the remaining thirty, the graded dosage-schedule des cribed above was used. The majority of these patients. received a dosage of $200 \mathrm{mg}$. weekly at some part of tho treatment, and for some who proved resistant, doses of $300 \mathrm{mg}$. were used for a time. Nevertheless, there was significantly less stomatitis in this group than in those receiving set courses of gold at a similar weekly dosages The difference between this group and those receivin the smaller doses is not significant as regards stomatitit nor are there any significant differences between any off the groups in any other respect, though it should be noted that Group I shows most dermatitis and is the onlyo

TABLE I

GOLD DOSAGE USED IN THIS INVESTIGATION

\begin{tabular}{|c|c|c|c|c|}
\hline \multicolumn{2}{|c|}{ Fibrinogen } & \multicolumn{2}{|c|}{ Erythrocyte Sedimentation Rate (mm./hr, Westergren) } & \multirow{2}{*}{$\begin{array}{c}\text { Weekly Dosage } \\
\text { of Gold } \\
\text { Compound (mg.) }\end{array}$} \\
\hline Mg. per cent. & Viscosity Difference & Female & Male & \\
\hline $\begin{array}{l}\text { Over } 550 \\
450-550 \\
\text { Under } 450\end{array}$ & $\begin{array}{l}\text { Over } 25 \\
20-24 \\
\text { Under } 20\end{array}$ & $\begin{array}{l}\text { Over } 25 \\
15-24 \\
15 \text { and under }\end{array}$ & $\begin{array}{l}\text { Over } 20 \\
10-19 \\
9 \text { and under }\end{array}$ & $\begin{array}{r}200 \\
100 \\
50\end{array}$ \\
\hline
\end{tabular}


TABLE II

RELATIONSHIP OF DOSAGE SCHEDULES TO TOXICITY IN RHEUMATOID ARTHRITIS TREATED WITH SOLGANAL B OLEOSUM

\begin{tabular}{|c|c|c|c|c|c|c|c|}
\hline \multirow{2}{*}{ Group } & \multirow{2}{*}{ Dosage } & \multicolumn{5}{|c|}{ Toxic Side-Effects } & \multirow{2}{*}{ Total Patients } \\
\hline & & Stomatitis & Dermatitis & Agranulocytosis & Jaundice & Grippe aurique & \\
\hline I & $200 \mathrm{mg}$. weekly for two courses of $2.5 \mathrm{~g}$. & 8 & 8 & 1 & 1 & 1 & 30 \\
\hline II & $100 \mathrm{mg}$. weekly for two courses of $1.5 \mathrm{~g}$. & 1 & 5 & 0 & 0 & 0 & 30 \\
\hline III & $\begin{array}{l}200-300 \mathrm{mg} \text {. weekly till E.S.R. normal: } \\
\text { then } 50 \mathrm{mg} \text {. weekly for } 8 \text { weeks }\end{array}$ & 4 & 6 & 0 & 0 & 2 & 30 \\
\hline III A & $\begin{array}{c}\text { Those in III who had an initial dose of } \\
300 \mathrm{mg} .\end{array}$ & 2 & 1 & 0 & 0 & 2 & 13 \\
\hline III B & $\begin{array}{l}\text { Those in III who had a dose of } 100 \mathrm{mg} \text {. } \\
\text { for the first two injections }\end{array}$ & 2 & 5 & 0 & 0 & 0 & 17 \\
\hline
\end{tabular}

group to show agranulocytosis or jaundice. A feature noted in Group III in two instances and in Group I once was a febrile reaction associated with generalized urticaria, erythema, and aggravation of the joint symptoms occurring about the 12th day of treatment. This reaction closely resembles serum sickness and may well be of the nature of an acquired sensitivity to the goldplasma-protein complex to which reference has already been made. In Group III it occurred only in those receiving a high loading dose and was then of such severity that a lower initial dosage was substituted. Since the initial two doses have been reduced to $100 \mathrm{mg}$. weekly it has not been encountered.

The data given in Table II can give only a very inadequate indication of the difference between these methods of treatment. The stomatitis and dermatitis encountered in Group III were very different in character from those in Groups I and II. In the latter they were frequently severe and associated with extensive ulceration of the mouth and gums and an eruption involving the face and limbs and sometimes also the trunk, the pain and itching sometimes causing serious loss of sleep. Moreover, both the stomatitis and dermatitis sometimes proved very intractable, the former sometimes lasting for a month or more, the latter for over a year in some instances. In Group III, on the other hand, the lesions of both mouth and skin were mild and transient and when they had subsided the gold treatment could, if necessary, be resumed with a modified dosage. Occasionally in this group a small scaly patch might persist on the arm or leg, but this did not cause discomfort.

Type of Preparation.-A number of preparations of gold have been used for the treatment of rheumatoid arthritis (Table III), but surprisingly little

TABLE III

ORGANIC GOLD COMPOUNDS USED IN TREATMENT

\begin{tabular}{|c|c|}
\hline Chemical Name & Proprietary Name \\
\hline $\begin{array}{l}\text { Sodium aurothiosulphate } \\
\text { Sodium aurothiopropanol sulphonate } \\
\text { Sodium aurothioglucose } \\
\text { Sodium aurothiomalate } \\
\text { Calcium aurothiomalate } \\
\text { Sodium aurothiosinamine benzoic acid } \\
\text { Gold-keratin compound }\end{array}$ & $\begin{array}{l}\text { Sanocrysin, Crisalbine } \\
\text { Allochrysine } \\
\text { Solganal B } \\
\text { Myocrisin } \\
\text { Aurocalcium } \\
\text { Lopion } \\
\text { Aurodetoxin }\end{array}$ \\
\hline
\end{tabular}

information is available on their relative toxicity. In acute toxicity experiments in animals (Sabin and Warren, 1941) toleration has proved high and has been found to depend less on the proportion of gold in a compound than on the nature of the radical to which the gold is attached and on its solubility. Thus the insoluble gold compounds such as calcium aurothiomalate were found least toxic, a dose of $5 \mathrm{~g} . / \mathrm{kg}$. being tolerated, whereas only $0.2 \mathrm{~g} . / \mathrm{kg}$. sodium aurothiomalate could be given. These doses, however, far exceed normal therapeutic doses in man which are of the order of $2 \mathrm{mg} . / \mathrm{kg}$. Chronic toxicity experiments in animals which would be much more informative do not appear to have been made.

Gold toxicity in patients under treatment with gold was studied by Hartfall and others (1937), who used a number of gold preparations and did not find them all equally toxic. Toxic reactions were more frequent with Myocrisin and Crisalbine, containing 50 and 37 per cent. of gold respectively, than with Solganal and Lopion containing 40 and 50 per cent. respectively, so that toxicity was unrelated to gold content. Severe reactions occurred most frequently with Myocrisin (6 per cent. of 67 cases) and least commonly with Solganal ( $1 \cdot 6$ per cent. of 301 cases). With all preparations, skin manifestations were more frequent than any other toxic reaction and generally took the form of an erythematous eruption with pruritus. Peripheral neuritis was encountered in two patients, both of whom had been treated with Myocrisin. Stomatitis and jaundice were also relatively more frequent in those having Myocrisin. Purpura occurred in nine of the total of 1,415 patients and agranulocytosis in one, the purpura being equally distributed amongst patients receiving different preparations of gold.

Snorrason (1952) treated patients with Sanocrysin, and serious toxic effects occurred in 6 per cent. Sundelin (1941) administered calcium gluconate at the same time as the gold in a proportion of his 
TABLE IV

TOXIC SYMPTOMS ARISING DURING TREATMENT WITH DIFFERENT PREPARATIONS OF GOLD

\begin{tabular}{|c|c|c|c|c|c|c|c|c|c|c|c|}
\hline \multirow{3}{*}{ Preparation } & \multirow{3}{*}{ Total Treated } & & & \multicolumn{6}{|c|}{ Toxic Side-Effects } & & \\
\hline & & \multicolumn{2}{|c|}{ Stomatitis } & \multicolumn{2}{|c|}{ Skin Eruption } & \multicolumn{2}{|c|}{ Albuminuria } & \multirow{2}{*}{ Polyneuritis } & \multirow{2}{*}{ Purpura } & \multicolumn{2}{|c|}{ Pruritus } \\
\hline & & No. & $\%$ & No. & $\%$ & No. & $\%$ & & & No. & $\%$ \\
\hline $\begin{array}{l}\text { Sodium aurothiomalate (aqueous) } \\
\text { Sodium aurothioglucose (oily) } \\
\text { Sodium aurothiomalate (oily) } \\
\text { Sodium aurothioglucose (aqueous) } \\
\text { Calcium aurothiomalate } \ldots\end{array}$ & $\begin{array}{r}33 \\
25 \\
2 \\
5 \\
4\end{array}$ & $\begin{array}{r}19 \\
8 \\
0 \\
3 \\
3\end{array}$ & $\begin{array}{l}63 \\
30\end{array}$ & $\begin{array}{r}11 \\
8 \\
0 \\
1 \\
1\end{array}$ & $\begin{array}{l}37 \\
30\end{array}$ & $\begin{array}{l}5 \\
5 \\
0 \\
2 \\
0\end{array}$ & $\begin{array}{l}20 \\
20\end{array}$ & $\begin{array}{l}2 \\
0 \\
0 \\
0 \\
0\end{array}$ & $\begin{array}{l}0 \\
1 \\
0 \\
0 \\
0\end{array}$ & $\begin{array}{l}2 \\
2 \\
0 \\
0 \\
1\end{array}$ & $\begin{array}{l}7 \\
8\end{array}$ \\
\hline
\end{tabular}

cases, but did not find the incidence of complications reduced.

The writer has, during the past 10 years, administered aurothiomalate (Myocrysin or Aurocalcium) to alternate patients with rheumatoid arthritis, and Solganal B to the remainder. In this way a group of 66 patients has been studied for a sufficient time to assess toxicity. The toxic symptoms are shown in Table IV; these patients were treated according to the schedule already described, in which the dose was greatly reduced when the erythrocyte sedimentation rate or plasma fibrinogen had reached a normal level. With this schedule, as already noted, there were no blood or liver disorders. Myocrisin was administered chiefly in aqueous solution, and Solganal B in a suspension in oil which was, until recently, the only form in which it was available. Since an aqueous solution of Solganal B has come available it has been studied alternately with the oily preparation in the Solganal group, and for comparison an oily suspension of Myocrisin is also now being used in alternate Myocrysin patients. The numbers treated with aqueous Solganal and oily Myocrisin on which data are available are as yet small and will be the subject of a later report, but they are included in the Table. Four patients treated with calcium aurothiomalate (Aurocalcium) are also included.

Results.-The most striking feature of this study is the high incidence of stomatitis in the Myocrisin treated series. Over half the patients had stomatitis at some time during the treatment, compared with only one out of eight receiving Solganal B. Despite the small numbers, this difference is highly significant. Dermatitis also tended to be more frequent in the Myocrisin group, but both in this group and in those receiving Solganal, it rapidly subsided when treatment was stopped, and it was found possible to resume treatment with a modified dosage where such a resumption was required. In a few instances, a small dry, scaly patch remained, generally in the region of the knee or elbow, but by then the disease had generally been controlled and only a low main- tenance dosage was thereafter required. Albumi- $\vec{\omega}$ nuria was found with similar frequency in those $\stackrel{N}{\circ}$ treated with Myocrisin and Solganal B. It was not $\frac{\varrho}{2}$ associated with symptomatology or with laboratory evidence of renal impairment in either group, and, i though dosage was modified when this complication arose, it was not found necessary to discontinue ${ }_{0}$ treatment. Polyneuritis supervened in two patients 은 treated with Myocrisin. In one of these, who has already been reported (Leiper, 1946), it subsided in $c$ the course of the next $3 \frac{1}{2}$ months when it was found that the rheumatoid process had been com- $\vec{\theta}$ pletely suppressed. In the second patient it arose at of a time when the value of monthly maintenance doses was being studied. As a monthly dose of $50 \mathrm{mg}$. had been found inadequate in earlier cases, $100 \mathrm{mg}$. monthly was used for this patient. The first six of these monthly maintenance doses were given without $\stackrel{0}{\circ}$ ill effect, but the seventh was followed by a severe $\varrho$ histamine-like reaction, characterized by flushing $\overrightarrow{\hat{O}}$ and loss of consciousness, the pulse becoming imper- 3 ceptible for about a minute. This was followed a day or two later by weakness of the right leg and both? arms which is still present 19 months later. It should be pointed out that in this case a dose of $100 \mathrm{mg}$. was? used at a time when both the erythrocyte sedimen- 3 tation rate and plasma fibrinogen were within normal limits, so that dosage was excessive according to the schedule already outlined. Histamine-like reactions characterized by flushing, headache, and sometimes unconsciousness with imperceptible pulse, $\rightarrow$ occurred in several patients treated with this batch of Myocrisin, but no others developed polyneuritis $\tilde{N}^{-}$ or other ill-effects. The samples had turned a darkbrown colour due to exposure to light and showed increased toxicity to chicks, and it was concluded $\omega$ that some highly toxic decomposition-product had? been formed from the gold salt. Similar histamine like reactions have been noted by others with certain $\Phi$ batches of Myocrisin (Barber, 1952), and the author ${ }^{+}$ had a similar experience with another batch, which $\frac{0}{0}$ had, however, been kept in a hospital dispensary for $\frac{\text { के }}{\circ}$ 6 years.

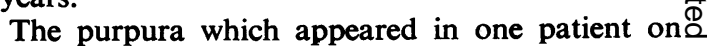


TABLE V

RELATIVE EFFICIENCY OF AUROTHIOGLUCOSE AND AUROTHIOMALATE IN PATIENTS IN WHOM TREATMENT WAS STARTED BEFORE AUGUST, 1951*

\begin{tabular}{|c|c|c|c|c|c|c|c|c|c|c|c|c|}
\hline \multirow{2}{*}{\multicolumn{2}{|c|}{ Preparation }} & & \multirow[t]{2}{*}{$\begin{array}{l}\text { Weekly } \\
\text { Dose }\end{array}$} & \multirow[t]{2}{*}{$\begin{array}{c}\text { Total } \\
\text { Patients }\end{array}$} & \multicolumn{5}{|c|}{ Results } & \multirow{2}{*}{$\begin{array}{l}\text { Refused } \\
\text { treatment } \\
\text { or ceased } \\
\text { to attend }\end{array}$} & \multicolumn{2}{|c|}{$\begin{array}{l}\text { Erythrocyte sedi- } \\
\text { mentation rate } \\
\text { finally normal in } \\
\text { three consecutive } \\
\text { monthly tests }\end{array}$} \\
\hline & & & & & No. & $\%$ & Improved & No change & Worse & & No. & $\%$ \\
\hline $\begin{array}{c}\text { Sodium Aurothioglucose } \\
\text { (Solganal B) }\end{array}$ & & & $\begin{array}{c}200-300 \mathrm{mg} \\
100 \mathrm{mg}\end{array}$ & $\begin{array}{l}56 \\
30\end{array}$ & $\begin{array}{r}22 \\
8\end{array}$ & $\begin{array}{l}39 \\
27\end{array}$ & $\begin{array}{l}30 \\
20\end{array}$ & $\begin{array}{l}2 \\
1\end{array}$ & $\begin{array}{l}0 \\
1\end{array}$ & 2 & $\begin{array}{l}38 \\
11\end{array}$ & $\begin{array}{l}68 \\
37\end{array}$ \\
\hline Sodium Aurothiomalate & . & . & $200-300 \mathrm{mg}$ & 27 & 10 & 37 & 16 & 0 & 0 & 1 & 15 & 55 \\
\hline Control & $\cdots$ & $\cdots$ & $\begin{array}{c}\text { Sterile almond } \\
\text { oil }\end{array}$ & 30 & 1 & 3 & 22 & 6 & 1 & 0 & 4 & 13 \\
\hline
\end{tabular}

* This table includes data from an earlier investigation (Ellman and others, 1940).

Solganal B was unassociated with thrombocytopenia and proved transient. Pruritus was complained of by two patients treated with Myocrisin and by two receiving Solganal. In the former it was limited to the anal region, in the latter it was more generalized. In all it was very transient and caused little inconvenience.

The number of patients treated with oily Myocrisin and aqueous Solganal is small, but it would appear that aqueous Solganal shows the same tendency to produce stomatitis as the aqueous preparation of Myocrisin. The use of Aurocalcium (calcium aurothiomalate) was discontinued after it had been used in four patients, all of whom developed toxic manifestations, three of them stomatitis. This stomatitis differed from that resulting from treatment with other gold preparations in being more widespread and always associated with an eruption on the inside of the cheeks.

Comparative Efficacy.-Diminished toxicity is of practical importance only if associated with undiminished therapeutic efficiency. Data on therapeutic effect are accordingly shown in Table V. In this table all patients on high dosage of Solganal B have been included, whether on the original twocourse scheme or on the later schedule, the results by these two methods being closely similar. A group of patients on a lower dosage of Solganal B has also been included. Myocrisin was not studied in the lower dosage or by the two-course scheme. The control group received injections of sterile almond oil once weekly as described in a previous paper (Ellman and others, 1940). Assessment of results was made on completion of treatment or at the end of 9 months.

The term "quiescent" is used to indicate the absence of pain, either spontaneous or on movement of the affected joints, associated with a normal erythrocyte sedimentation rate and plasma fibrinogen. The erythrocyte sedimentation rate, estimated by the Westergren method, was considered normal when below $10 \mathrm{~mm}$. in the male and $16 \mathrm{~mm}$. in the female. A number of patients still complained of slight residual pain after the blood findings had become normal. Some of these showed evidence of osteo-arthritis in the painful joints, but were not labelled as quiescent.

It is clear from the data in Table $\mathrm{V}$ that Myocrisin has no greater therapeutic effect than Solganal $B$. The indications are rather that its effect may be less, fewer attaining a normal erythrocyte sedimentation rate amongst those treated with it, but the differences are not significant and may well be due to more frequent interruption of treatment because of toxicity in this group. Nor is there any significant difference between the Myocrisin group and those receiving small doses of Solganal. There are, of course, highly significant differences between both the Myocrisin and large-dose Solganal group and the controls, and the differences between high-dose Solganal and low-dose Solganal, and between low-dose Solganal and the controls are significant as regards the erythrocyte sedimentation rate.

Data are unfortunately not now available regarding return to work amongst the earlier cases studied, including those in the small-dose Solganal and control groups, but of the later high-dose Solganal and Myocrisin groups, all those below the age of 65 have returned to work, apart from one patient who also had severe disk degeneration.

\section{Discussion}

Preparation.-- It is clear from all data so far considered that toxicity does not depend on the proportion of gold in the compound used, and some feature in the organic part of the molecule must 
therefore be held responsible. On the other hand, the toxic symptoms are those which commonly arise in heavy metal poisoning and are presumably due to the gold ion. This may be explained if it is assumed that the organic fraction determines the distribution in the tissues and eventual disposal. As the excretion of gold is extremely slow, it is unlikely that relative excretion rates play an important part in toxicity, and it seems more probable that distribution in the body is the main factor. The importance of molecular size in determining the relative concentration in diseased tissues has already been noted in this connection, and it is therefore of interest that, whereas Myocrisin, which is more toxic, has a molecular weight of 390 , the molecular weight of Solganal B is, by virtue of a certain degree of polymerization, of the order of 1,000 . The fact that the Solganal used for the greater part of these trials was in an oily suspension and the Myocrisin was in aqueous solution may have played a part. If, for example, a higher peak blood level were attained after injection of an aqueous solution, the combining-power of the plasma proteins for gold might be exceeded and permit of greater diffusion of the gold through undamaged capillaries into tissues other than those of the diseased joints.

An important point which arises from this study is that total dosage of gold is not important. One patient in this series had as much as $9 \mathrm{~g}$. without a pause, and apart from a transient pruritus and gingivitis, suffered no ill-effect. Though gold must undoubtedly accumulate in the tissues, it would appear to become fixed and to be no longer capable of producing toxic effects, though rarely a toxic effect on the blood-forming organs has been known to arise some time after treatment, possibly due to reactivation of gold fixed in the tissues.

Duration of Treatment.-A decision as to the duration of treatment must depend on whether gold therapy is regarded as curative or suppressive. It is well recognized that relapses are frequent in patients treated with gold, though they may not occur for some considerable time after the cessation of treatment, particularly if high dosage has been used. As, however, the excretion of gold is very slow and may not be complete after 3 years, a suppressive action is not ruled out. It is indeed supported in some measure by the differential agglutination test, whose titre is not at once reduced by successful aurotherapy, and may be higher when the disease has reached the quiescent stage than before starting treatment. In this respect gold resembles cortisone, which is also without effect on the differential agglutination test. Moreover, in arthritis of known aetiology, as, for example, the infective arthritis of rats, which histologically shows a close resemblance to rheumatoid arthritis, the causative virus has not been found susceptible, though the disease process can be completely suppressed by aurotherapy (Sabin and Warren, 1940).

If aurotherapy is merely suppressive, it would seem reasonable to provide some sort of maintenance treatment once the quiescent stage has been reached. This poses a difficult problem, and two alternative solutions are at present being studied:

(i) To give maintenance doses of, say, $50 \mathrm{mg}$. every 4th week for a prolonged period, until, for example, all signs of activity have been absent for 3 years. A longer period may, of course, prove to be necessary, and the differential agglutination test, if it is indeed an index of the continued presence of the aetiological agent, may assist in this respect. Even on such a maintenance dosage, the condition may recur, as happened in one patient in the present series. If this should happen the dosage should not be increased unless the plasma fibrinogen content rises, but the injections may be given more frequently.

(ii) To keep the patient under observation without maintenance dosage of gold, the erythrocyte sedimentation rate and plasma fibrinogen being taken at intervals of 3 to 6 months. If evidence of relapse appears the treatment may then be resumed.

It is too soon at present to say which of these alternatives should be preferred. The danger of $\stackrel{\varnothing}{\AA}$ relapse is probably greater when treatment is inter- $\overrightarrow{\vec{O}}$ rupted, as patients on this routine are more likely 3 to stop attending, and may not reappear till the relapse is in an advanced stage. This must be placed against the possibility of toxic effects arising from maintenance dosage, if the former alternative is adopted.

\section{Summary}

Alternate patients on gold therapy for rheumatoid arthritis received aurothioglucose (Solganal B oleosum) and aurothiomalate (Myocrisin or Aurocalcium).

The aurothioglucose proved significantly less $\mathcal{O}$ toxic, the incidence of stomatitis being halved. N Polyneuritis occurred in two patients receiving auro- N thiomalate, but in none of those treated with aurothioglucose. The possible factors responsible for this difference in toxicity are discussed.

No significant difference in therapeutic efficiency was found between these two compounds.

A method is described whereby the greater $\frac{T}{0}$ therapeutic efficiency of a high dosage (up to $200 \mathrm{mg}$. weekly) of gold in rheumatoid arthritis may be $\stackrel{\sim}{\mathbb{D}}$ attained without the greater incidence of side-effects 
normally present with such a dose. The method depends on an adjustment of gold dosage in relation to the activity of the disease process as determined by the fibrinogen content of the plasma.

In a series of 66 patients treated in this way, no blood dyscrasias or chronic skin eruptions were encountered, and all those under the age of 65 were able to return to work. The blood sedimentation rate was maintained at a normal level in 57 per cent. of patients treated on this schedule as compared with 37 per cent. of patients receiving a standard dosage of $100 \mathrm{mg}$. weekly. Only two (4 per cent.) failed to improve.

I wish to thank Messrs Schering for supplies of Solganal $B$ aquosum for use in this trial, and Messrs May and Baker for kindly carrying out toxicity tests on a sample of Myocrisin.

\section{REFERENCES}

Barber, S. (1952). Personal communication.

Bertrand, J. J., Waine, H., and Tobias, C. A. (1948). J. Lab. clin. Med., 33, 1133.

Browning, J. S., Rice, R. M., Lee, W. V., and Baker, L. M. (1947). New Engl. J. Med., $237,428$.

Comroe, B. I. (1945). J. Amer. med. Ass., 128, 848.

Egelius, N., Hävermark, N. G., and Nyström, G. (1952). Annals of the Rheumatic Diseases, 11, 17.

Ellman, P., and Lawrence, J. S. (1935). Brit. med. J., 2, 622.

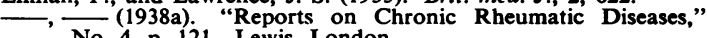
No. 4 , p. 121. Lewis, London. (1938b). Postgrad. med. J., 14, 275.

- - and Thorold, G. P. (1940). Brit. med. J., 2, 314

Fraser, T. N. (1945). Annals of the Rheumatic Diseases, 4, 71 .

Freyberg, R. H., Block, W. D., and Lavey, S. (1941). J. Clin. Invest., 20, 401.

Goldie, W. (1939). Annals of the Rheumatic Diseases, 1, 319.

Hartfall, S. J., Garland, H. G., and Goldie, W. (1937). Lancet, 2, 784.

Hartung, E. F., Cotter, J., and Gannon, C. (1941). J. Lab. clin. med. 26, 1750 .

Kling, D. H., Vento, J. P., and Sashin, D. (1949). Rheumatism, 5, 93. Lawrence, J.'S. (1949). Annals of the Rheumatic Diseases, 8, 209. (1950). J. clin. Path., 3, 332.

Leiper, E. J. R. (1946). Brit. med. J., $2,119$.

Libenson, L. (1945). Exp. Med. Surg., 3, 146.

Menkin, V. (1936). J. exp. Med., 64, 485.

Price, A. E., and Leichtentritt, B. (1943). Ann. intern. Med., 19, 70.

Price, A. E., and Leichtentritt, B. (1943). Ann. intern.
Sabin, A. B., and Warren, J. (1940). J. Bact., 40, 823.

Sabin, A. B., and Warren, J. (1940). J. Bact.,40,

Short, C. L., Beckman, W. W., and'Bauer, W. (1946). New Engl. J. Med., 235, 362.

Snorrason, E. (1952). Acta med. scand., 142, 249.

Sundelin, F. (1941). Ibid., Suppl. 117.

Facteurs posologiques et toxiques de la chrysothérapie de l'arthrite rhumatismale

RÉsumÉ

Au cours de la chrysothérapie de l'arthrite rhumatismale les malades alternatifs ont reçu de l'aurothioglucose (Solganal B oleosum) et les autres de l'aurothiomalate (Myocrisine ou Aurocalcium).
L'aurothioglucose s'est montrée clairement moins toxique, réduisant de moitié la fréquence de la stomatite. La polynévrite survint chez deux malades traités par l'aurothiomalate, sans apparaître chez ceux traités par l'aurothioglucose. On discute les facteurs pouvant expliquer cette différence de toxicité.

On n'a pas trouvé de nette différence entre ces deux produits en ce qui concerne leur efficacité thérapeutique.

On décrit une méthode qui dans l'arthrite rhumatismale augmente l'efficacité thérapeutique grâce à l'emploi de fortes doses (jusqu'à $200 \mathrm{mg}$. par semaine) sans augmenter la fréquence des incidents secondaires que de telles doses entrainent généralement. D'après cette méthode on ajuste les doses des sels d'or en fonction de l'activité morbide indiquée par le taux sanguin du fibrinogène.

Dans un groupe de 66 malades ainsi traités on n'a pas observé de dyscrasie sanguine ou d'exanthème et tous les maldes âgés de moins de 65 ans ont pu reprendre leur travail. La vitesse de la sédimentation globulaire s'est maintenu normale chez $57 \%$ des malades traités par cette méthode et chez $37 \%$ seulement de ceux traités par des doses habituelles de $100 \mathrm{mg}$. par semaine. Deux malades seulement $(4 \%)$ n'accusèrent pas d'amélioration.

Factores posológicos y tóxicos en la auroterapia de la artritis reumatoide

\section{Sumario}

En el curso de la crisoterapia de la artritis reumatoide los enfermos alternativos fueron tratados con aurotioglucosa (Solganal B oleosum) y los demás con aurotiomalato (Myocrisin o Aurocalcium).

La aurotioglucosa resultó ser netamente menos tóxica, reduciendo de la mitad la incidencia de estomatitis. $\mathrm{La}$ polineuritis sobrevino en dos enfermos tratados con el aurotiomalato sin aparecer en los tratados con aurotioglucosa. Se discute los factores probables que motivan esta diferencia de toxicidad.

No se encontró diferencia significante en la eficacia terapéutica de los dos productos.

Se describe un método de tratamiento de la artritis reumatoide que permite aumentar su eficacia con altas dosis (hasta $200 \mathrm{mg}$. semanales) de oro sin aumentar la incidencia de efectos secundarios, habituales con tales dosis. Este método consiste en un ajuste de las dosis de sales de oro en relación a la actividad morbosa reflejada en la tasa de fibrinógeno en el plasma.

En un grupo de 66 enfermos así tratados no hubo discrasia sanguinea ni exantema y todos los enfermos de menos de 65 años de edad pudieron volver a su trabajo. La velocidad de sedimentación globular mantúvose normal en el $57 \%$ de los enfermos tratados con este método y tan sólo en el $37 \%$ de los tratados con dosis habituales de $100 \mathrm{mg}$. por semana. Dos enfermos solamente $(4 \%)$ no acusaron mejoría alguna. 